\title{
Asbestos in Canada: time to change our legacy
}

\author{
Trevor Dummer PhD, Carolyn Gotay PhD
}

I n May 2015, delegates at the Conference of the Parties to the Rotterdam Convention will once again consider adding chrysotile asbestos to the treaty governing the trade in substances harmful to health. In relation to asbestos, Canada's role in the international community has been questionable. ${ }^{1,2}$ In 2011, Canada was the only member of the Rotterdam Convention to oppose placing chrysotile on the international treaty of hazardous substances, although in 2012 Canada announced that it was no longer opposed to the move. However, a coalition of seven member nations (India, Kazakhstan, Kyrgyzstan, the Russian Federation, Ukraine, Vietnam and Zimbabwe) blocked adding chrysotile to the treaty in 2013, and thus currently chrysotile is not included on the convention's list of hazardous substances. Although Canada has at last ended domestic extraction and export of asbestos, it has not banned asbestos use, unlike many developed nations, including Australia and all countries within the European Union. ${ }^{1,2}$ Furthermore, Canada is not an advocate for ending asbestos use worldwide.

Asbestos is a naturally occurring fibrous silicate mineral that exists in two major forms: amphibole (which includes amosite, crocidolite, tremolite, anthophyllite and actinolite) and serpentine (also known as chrysotile or "white asbestos"). ${ }^{2}$ All forms of asbestos are classified by the International Agency for Research on Cancer (IARC) as Group 1 human carcinogens that cause mesothelioma and cancers of the lung, larynx and ovary. ${ }^{3}$ Asbestos has also been implicated in other cancers, including pharyngeal, colorectal and stomach cancer. ${ }^{3}$ Mesothelioma occurs most commonly in the pleura (about $70 \%-80 \%$ of cases) and peritoneum (about $25 \%$ of cases), but occasionally in the pericardium. Although the health effects of the two forms of asbestos are the same, ${ }^{4,5}$ the IARC acknowledges that the potency of effects varies, with amphibole asbestos being a more potent carcinogen. Both forms of asbestos cause asbestosis, a debilitating lung disease for which there is no effective treatment and which is associated with an increased risk of lung cancer. ${ }^{6}$

Canada has a long history of production, use and export of asbestos, dating back to the first asbestos mine in Quebec in $1874 .{ }^{5}$ As recently as 2010, about 100000 tonnes of chrysotile asbestos was produced in Quebec, most of which was exported. ${ }^{7}$ Canada's last asbestos mine closed in 2012 and was later abandoned when a provincial loan of $\$ 58$ million, offered in 2012 to enable the mine to extract asbestos for a further 20 years, was cancelled by Quebec's incoming government.

Canada is no longer a major contributor to the export of this environmental and occupational carcinogen, but two major asbestos-related issues remain substantial concerns for Canadian public health. First, the legacy of Canada's asbestos industry, and the fact that asbestos is present in many buildings throughout Canada, means the country is facing a considerable longterm burden of asbestos-related disease. ${ }^{8}$ Second, Canada continues to import and use a range of asbestos-containing products (Appendix 1, available at www.cmaj.ca/lookup/suppl/doi:10.1503/ cmaj.150269/-/DC1), with potentially serious health consequences.

Mesothelioma incidence and mortality continues to increase in Canada. ${ }^{9,10}$ This increase relates primarily to past occupational and environmental exposures. ${ }^{89}$ Given Canada's long association with the asbestos industry, the long latency of asbestos-related disease and the fact that a great deal of asbestos is still present in buildings in Canada, mesothelioma deaths will continue to rise for some years. Furthermore, it is estimated that for every case of mesothelioma, there are two cases of asbestos-related lung cancer. ${ }^{9}$ The tragic legacy of asbestos exposure,

\section{KEY POINTS}

- Canada still imports chrysotile asbestos products.

- Chrysotile asbestos has been classified as a carcinogen by the International Agency for Research on Cancer.

- At the upcoming Conference of the Parties to the Rotterdam Convention in May 2015, Canada should add its voice to those lobbying for an outright ban on all asbestos use.

- Canadian public health policy should include a plan for a time-specific ban on all importation and use of asbestos, as has been instituted in other jurisdictions.
Competing interests: None declared.

This article has been peer reviewed.

Correspondence to:

Trevor Dummer,

trevor.dummer@ubc.ca

CMAJ 2015. DOI:10.1503 /cmaj.150269 
even among individuals who never knew they had been exposed, continues to affect many Canadians and their families. ${ }^{11}$ Nationwide public education campaigns concerning asbestos risks, especially for those undertaking home renovations, are therefore crucial.

It is of concern that asbestos products continue to be imported and used in Canada (Appendix 1). Although the quantity has been reduced from $\$ 80$ million per year of asbestos imported a decade ago, the industry was worth almost $\$ 6$ million in 2014 (Appendix 1), which is a substantial amount. For example, the $\$ 4.6$ million worth of asbestos-containing friction materials (largely brake pads) imported in 2014 represents $14 \%$ of the total dollar value of these imported products. Other asbestos-containing products imported include construction materials. It is ironic that at the same time many buildings in Canada are having asbestos removed, at a considerable economic cost, asbestos products are being used in new buildings.

Canada's support for the chrysotile industry has long been justified by both government and industry sources with the argument that chrysotile can be used safely under controlled conditions. This argument is widely discredited by scientific evidence showing that exposure to chrysotile asbestos is associated with cancer and that exposure to asbestos is difficult to control adequately in occupational and environmental settings. ${ }^{2,3}$ Globally, about two million tonnes of chrysotile asbestos is used annually, mostly in developing regions of Asia (India and China), the former Soviet Union and South Africa. The legacy of this continuing international trade will include new cancer diagnoses and devastating health effects for years to come - many of these in developing countries with inadequate or underfunded health systems. Even though Canada is no longer the world's largest exporter of asbestos, by not ending chrysotile imports or lobbying for a global ban on use of all forms of asbestos, Canada remains complicit in an international industry that is responsible for about 100000 avoidable deaths annually. ${ }^{12}$

Asbestos-related disease is wholly preventable through the safe removal of existing asbestos products from the environment and, moving forward, the simple action of a global ban on the pro- duction and use of asbestos-related products. It is time that Canada accepts the scientific consensus that chrysotile asbestos has unacceptable health consequences $^{2}$ and institutes a public health policy in line with scientific evidence. The upcoming Rotterdam Convention conference offers Canada the opportunity to lobby actively for chrysotile's inclusion in the treaty of hazardous substances. We urge Canadian policy-makers to instigate a time-specific ban on all asbestos use in Canada, and support a global ban on asbestos use.

\section{References}

1. Attaran A, Boyd DR, Stanbrook MB. Asbestos mortality: a Canadian export. CMAJ 2008;179:871-4.

2. LaDou J, Castleman B, Frank A, et al. The case for a global ban on asbestos. Environ Health Perspect 2010;118:897-901.

3. IARC Working Group on the Evaluation of Carcinogenic Risks to Humans. A review of human carcinogens. Part C: arsenic, metals, fibres, and dusts. Lyon (France): International Agency for Research on Cancer; 2009. Available: http://monographs.iarc.fr /ENG/Monographs/vol100C/index.php (accessed 2014 Nov. 6).

4. De Guire L, Camus M, Case B, et al. The epidemiology of asbestos-related diseases in Quebec. Montréal: Institut national de santé publique du Québec; 2004. Available: www.inspq.qc. $\mathrm{ca} /$ pdf/publications/293-EpidemiologyAsbestos.pdf (accessed 2015 Apr. 16).

5. Haynes RC. A worn-out welcome. Environ Health Perspect 2010;118:A298-303.

6. Gan WQ, Demers PA, McLeod CB, et al. Population-based asbestosis surveillance in British Columbia. Occup Environ Med 2009;66:766-71.

7. Virta RL. US Geological Survey 2013 minerals yearbook: asbestos. US Department of the Interior; 2014. Available: minerals. usgs.gov/minerals/pubs/commodity/asbestos/myb1-2013-asbes. pdf (accessed 2015 Apr. 25).

8. Krupoves A, Camus M, De Guire L. Incidence of malignant mesothelioma of the pleura in Québec and Canada from 1984 to 2007, and projections from 2008 to 2032. Am J Ind Med 2015;58:473-82.

9. Marrett LD, Ellison LF, Dryer D. Canadian cancer statistics at a glance: mesothelioma. CMAJ 2008;178:677-8.

10. Table 102-0522: Deaths, by cause, Chapter II: neoplasms (C00 to D48), age group and sex, Canada. Ottawa: Statistics Canada; 2015. Available: www5.statcan.gc.ca/cansim/a26?lang=eng \&id=1020522 (accessed 2015 Apr. 20).

11. Sieniuc K. The case against asbestos: accidental exposure is entirely preventable. Available: www.theglobeandmail.com/life/ health-and-fitness/health/the-case-against-asbestos-accidental -exposure-entirely-preventable/article19677984 (accessed 2015 Apr. 20).

12. Asbestos: elimination of asbestos-related diseases. Geneva: World Health Organization; 2014. Available: www.who.int/ mediacentre/factsheets/fs343/en/(accessed 2014 Nov. 7).

Affiliation: School of Population and Public Health, Cancer Prevention Centre, University of British Columbia, Vancouver, BC

Contributors: Both authors wrote the article, approved the version to be published and agreed to act as guarantors of the work.

Acknowledgement: The authors dedicate this commentary to Dr. Patricia Martens, who died from mesothelioma on Jan. 10, 2015. Dr. Martens was a passionate advocate for banning all asbestos use. 